\title{
Influence of Key Performance Indicators in Marketing on the Financial Situation of Wine Producers Using ICT
}

\author{
Klára Hennyeyová ${ }^{1}$, Erik Janšto $^{1}$, Edita Šilerová ${ }^{2}$ Peter Stuchlý ${ }^{1}$ \\ ${ }^{1}$ Faculty of Economics and Management, Slovak University of Agriculture in Nitra, Slovak Republic \\ ${ }^{2}$ Faculty of Economics and Management, Czech University of Life Sciences Prague, Czech Republic
}

\begin{abstract}
Marketing is one of the key elements of the success of all companies, including the wine sector. Given the importance of wine producers for agriculture, it is important to define and monitor key performance indicators in marketing (KPIs) for a successful stay in the market and a competitive position at home and abroad. Today, the increase in competitive advantage includes mainly marketing, innovation and information and communication technologies. New digital tools and innovations have changed the way we approached data and decisions. A modernly adapted and effective strategic marketing strategy represents for wine companies an understanding mainly of their possibilities as well as the possibilities to influence the customer. This article evaluates the key performance indicators in marketing (KPI) and its relationship and impact on the financial situation of wine producers in Slovakia. The research sample includes 80 respondents. We obtained the primary data through a questionnaire, which was filled in by the leaders of wine companies. We verified the accuracy by means of descriptive statistics and multiple linear regression and Kruskall-Wallis test. We have verified the reliability of the data with the Cronbach alpha test. We have formulated scientific assumptions for in-depth analysis: hypothesis 1 - assumes that key performance indicators have a significant influence on financial situation of selected companies, hypothesis 2 - the use of ICT in marketing is statistically related to the key performance indicators.

The results showed a statistically significant impact of KPIs on the financial situation of companies. We have identified significance in customer satisfaction and loyalty, brand awareness and return of investment. However, we were unable to statistically confirm the impact of other indicators (sales growth, market share, gaining new customers). We also identified significant differences in the use of ICT in marketing with key performance indicators in hiring new customers and return on investment. This research contributes positively to the importance of brand building in the eyes of customers as well as customer service, building loyalty and satisfaction, which returns to the loyal approach of customers to the repurchase of wine products and provides advice for professionals. Return on investment helps in more accurate business decisions that can be used when purchasing new equipment (technology), hiring employees, or properly assessing the profitability of marketing strategies.
\end{abstract}

\section{Keywords}

Marketing, key performance indicators, ICT, loyalty, wine producers.

Hennyeyová, K, Janšto, E., Šilerová, E. and Stuchlý, P. (2021) "Influence of Key Performance Indicators in Marketing on the Financial Situation of Wine Producers Using ICT", AGRIS on-line Papers in Economics and Informatics, Vol. 13, No. 3, pp. 49-58. ISSN 1804-1930. DOI 10.7160/aol.2021.130305.

\section{Introduction}

Time has witnessed significant changes in marketing and marketing strategies. Over time, various trends have emerged in sustainability, social needs and consumer behavior. The reassessment of various issues and phenomena has resulted in a new direction in marketing strategies (Kumar et al., 2012). Marketing strategy describes how a company will fulfill marketing activities and decisions through which it will create and maintain a competitive advantage (Varadarajan et al., 2001). It also focuses on ways to differentiate itself from its competitors, making maximum use of its specific advantages to deliver the best possible added value to customers in the business environment (Jain et al., 2012). The focus 
on the consumer has also been confirmed Charter et al. (2006), which reflects changes in customer requirements and expectations. It confirms that companies should react flexibly and adopt different strategies in order to gain a competitive advantage in the market. Moreover, advertising messages should be tailored based on specific segment characteristics (Šedík et al., 2019). Ferrell and Hartline (2007) also highlight the importance of activities related to maintaining good relationships with employees and supply chain partners. Śimek et al. (2008) adds that in the case of any long-term relationship, the basic pillar is based on mutually beneficial cooperation. Therefore, the choice of the right strategic marketing procedure is often a decisive factor for the successful growth of the company's performance. With the advent of technological progress and innovation, there has been a growing interest among professionals to access documentation that would bring up-to-date measures in marketing activities that could have an impact on improving the financial performance of companies. Grønholdt and Martensen (2006) addressed key marketing performance measures and developed a quality list of the most valuable measures. There is also a discussion in the marketing literature about the constant emphasis on assessing the financial responsibility of marketing functions in companies (O'Sullivan et al., 2009; Grønholdt and Martensen; 2006; Rust et al., 2004; Gotteland et al., 2020). It is desirable to point out the impact of marketing and marketing decisions on key business results and return on investment. Despite this trend, there are still companies on the market that work with data that often misnames and transforms data into inappropriate indicators. On the other hand, few companies know that it is necessary to monitor key success indicators in particular. In this context, managers should have knowledge of the right indicators of success for today's market requirements. According to Badawy et al. (2016) there are 4 ways to measure performance indicators:

1. key result indicators - brings information on the achievement of a perspective or critical factor,

2. result indicators - provide information on the work performed and tasks completed,

3. performance indicators - brings information's that contain things that companies must do,

4. key performance indicators - bring advice to the company on exactly what to do to improve performance.
Empirical studies demonstrate different approaches to key performance indicators in different directions. Granberg and Munoz (2013) identified 5 areas for action to quickly obtain information if a process does not meet the required standard. Elshakour et al. (2013) came up with the 10 most important KPIs, which include profitability, quality of service and work, growth, customer satisfaction, financial stability, cash flow, market share, security, business efficiency and planning efficiency. Khalifa and Khalid (2015) developed a set of strategic key performance indicators to monitor and improve performance in the tertiary sector. And many other studies (Peng et al., 2011; Diamantini et al., 2013; Keck and Ross, 2014; Ning et al., 2011; Stefanovic, 2014; Suryadi, 2007; An et al., 2004) provide important information and findings about KPIs in the areas of business, education, or information technology. At the heart of these studies is knowledge for companies to improve organizational efficiency by identifying metrics that contribute to long-term success. Greve (2011) considers in performance to be a key influence on the strategic direction of managers. It states that the indicators of sales growth in the target market is a criterion for managers to assess the relative position of the company in relation to competitors and, to some extent, to re-evaluate their marketing strategy. Berg (2017) combines sales growth with competitiveness. It notes that market share helps managers assess primary and selective market demand. It also adds that market share allows to assess not only the overall growth or decline of the market, but also trends in customer selection, which can have a significant impact on the financial situation of the company. There may also be a situation where the market is highly homogeneous, and customers face their indecision in distinguishing between products and their quality. In this case, the cost of detailed information about possible product differences may be too expensive or require time for in-depth analysis, and therefore companies must use the external success factor as brand awareness, which can be a decisive factor in purchasing (Shaw, 1981). This was confirmed by an extensive study by Warlop et al. (2005), which pointed out that, in specific circumstances, brand awareness is closely linked to a company's better market performance. Wangenheim and Bayón (2004); Anderson and Sullivan (1993) state that the constant fulfillment of customer needs leads to their satisfaction, which increases customer loyalty, and this leads to an increase in the company's reputation. The positive relationship between customer satisfaction 
and loyalty has been demonstrated by several studies (Mittal and Kamakura, 2001; Anderson and Sullivan, 1993). Customer loyalty is linked to the frequency of more frequent purchases, which provide increased revenue and an improved financial situation (Homburg and Fürst, 2005). Last, but not least, return on investment (ROI), which can have a positive effect on performance. This is based on the research of Krizanova et al. (2019), who pointed out that the return on investment is used as a standard metric for evaluating investments in communication tools. Petrilák et al. (2020) state that due to the increased bargaining power of customers, more and more companies are trying to adapt new business techniques as well as innovations in the form of technologies to more effective strategic management. Hallová and Hanova (2019) confirm that the use of specific information and communication technologies significantly increases the precondition for the success of companies in economic activity.

\section{Material and methods}

The article analyzes practical indicators that examine the overall performance of the company in relation to the primary goal of companies, achieving financial stability, especially in the agricultural wine sector. The main goal is to analyze the impact of key performance indicators in marketing (sales growth, market share, gaining new customers, brand awareness, customer satisfaction and loyalty, return on investment) and their potential in business development. The research focuses on the financial situation of wine producers in Slovakia, as well as the use of information and communication technologies in marketing. The article is the result of internal specific research conducted at the Department of Informatics, Faculty of Economics and Management, SPU in Nitra.

The research was based on a descriptive-analytical method using convenient sampling to achieve the objectives of the study. The research sample consisted of 80 companies, represented by middle and senior management from all wine-growing areas in Slovakia. Several scientific methods were used to evaluate the questionnaire. We used the method of analysis and comparison to identify the current state of KPIs and the use of ICT in marketing. We used the method of synthesis to clarify new and previously undefined relationships and patterns from the used literature. We used the induction method to create hypotheses in which we came to the essence of the phenomenon and the formulation of conclusions. Furthermore, the method of deduction allowed us to derive new statements more accurately, where we tested whether the chosen hypotheses are able to explain the investigated fact. The questionnaire survey was compiled electronically via Google Forms and data were collected and processed via MS Excel, in which basic tables and graphs were processed. Statistical processing and evaluation were performed via IBM SPSS software. The questionnaire covers all dimensions of independent and dependent variables that allow the testing of hypotheses. However, based on the obtained results, we first used Cronbach alpha to measure the internal consistency, which ensures the validity of the design of the questionnaire as a tool for data collection.

\begin{tabular}{|l|c|c|c|}
\hline \multicolumn{2}{|l|}{ Scope of reliability analysis } & Variables & Cronbach's alpha \\
\hline All variable items & \multirow{2}{*}{ H1 } & 7 & 0.778 \\
\cline { 1 - 2 } $\begin{array}{l}\text { Variables } \\
\text { to Hypothesis H1 }\end{array}$ & 6 & 0.731 \\
\hline All variable items & \multirow{2}{*}{ H2 } & 7 & 0.712 \\
\cline { 1 - 2 } $\begin{array}{l}\text { Variables } \\
\text { to Hypothesis H2 }\end{array}$ & 6 & 0.731 \\
\hline
\end{tabular}
$\begin{aligned} & \text { Source: own research and processing } \\
& \text { Table 1: Internal Consistency Coefficients (Cronbach Alpha). }\end{aligned}$

As the Table 1 shows, testing the reliability of the questionnaire data was sufficient for the selected hypotheses. As stated by Sekaran and Bougie (2010) the reliability may be $(0.60)$ or higher to indicate adequate internal consistency. The characteristics of the research sample include the legal form of the business, the size of the business, the years of existence of the winery and the vineyards regions (Table 2).

Formulated hypothesis was tested using statistical method multiple linear regression, which is used to predict a continuous dependent variable (financial situation) and several independent variables (key performance indicators), as well we also used nonparametric Kruskall-Wallis test. During testing hypothesis, if p-value is lower than significant level, in case of IBM SPSS, its 0.05, than null hypothesis is rejected and alternative hypothesis confirm. To achieve deeper analysis of research objectives, we defined following hypotheses:

Hypothesis 1 - We assume that key performance indicators have a significant influence on the financial situation of selected companies.

Hypothesis 2 - The use of ICT in marketing is statistically related to the key performance indicators. 


\begin{tabular}{|c|c|c|c|}
\hline Variable & Category & Number & Percentage $\%$ \\
\hline \multirow[t]{6}{*}{ Legal form } & Private limited company & 51 & $63.75 \%$ \\
\hline & Self-employed farmer & 6 & $7.50 \%$ \\
\hline & Joint stock company & 7 & $8.75 \%$ \\
\hline & Cooperatives & 6 & $7.50 \%$ \\
\hline & Special forms of ownership & 2 & $2.50 \%$ \\
\hline & Self-employed person & 8 & $10.00 \%$ \\
\hline \multirow[t]{2}{*}{ Size of company } & micro company (0-9 employees) & 47 & $58.75 \%$ \\
\hline & small company (10-49 employees) & 33 & $41.25 \%$ \\
\hline \multirow[t]{3}{*}{ Years of existence } & $1-5$ years & 13 & $16.25 \%$ \\
\hline & $5-10$ years & 20 & $25.00 \%$ \\
\hline & more than 10 & 47 & $58.75 \%$ \\
\hline \multirow[t]{6}{*}{ Location } & Little Carpathians Wine Region & 34 & $42.50 \%$ \\
\hline & South Slovak Wine Region & 17 & $21.25 \%$ \\
\hline & Nitra Wine Region & 12 & $15.00 \%$ \\
\hline & East Slovak Wine Region & 4 & $5.00 \%$ \\
\hline & East Slovak Wine Region & 9 & $11.25 \%$ \\
\hline & Tokaj Wine Region & 4 & $5.00 \%$ \\
\hline
\end{tabular}

Source: own research and processing

Table 2: Description of study sample according to the demographic variables.

\section{Results and discussion}

The questionnaire survey was focused on companies in the field of wine production. The reference sample consisted of 57 microenterprises and 33 small enterprises, which evaluated their key indicators of marketing performance, the general financial situation, and the implementation of ICT in marketing activities. The following section focuses on the analysis of financial, market and customeroriented indicators. We also study the use of ICT in selected companies.

The results of the survey showed several interesting findings. If we look at Figure 1, there is a disproportion between some indicators - the customer-oriented area, 51\% - 54\% of companies achieve above-standard results in awareness of their brand and customer satisfaction and loyalty. It is important to note that these are mainly companies with a 5-10-year existence. From this we can assume that companies apply mainly processes that put the customer

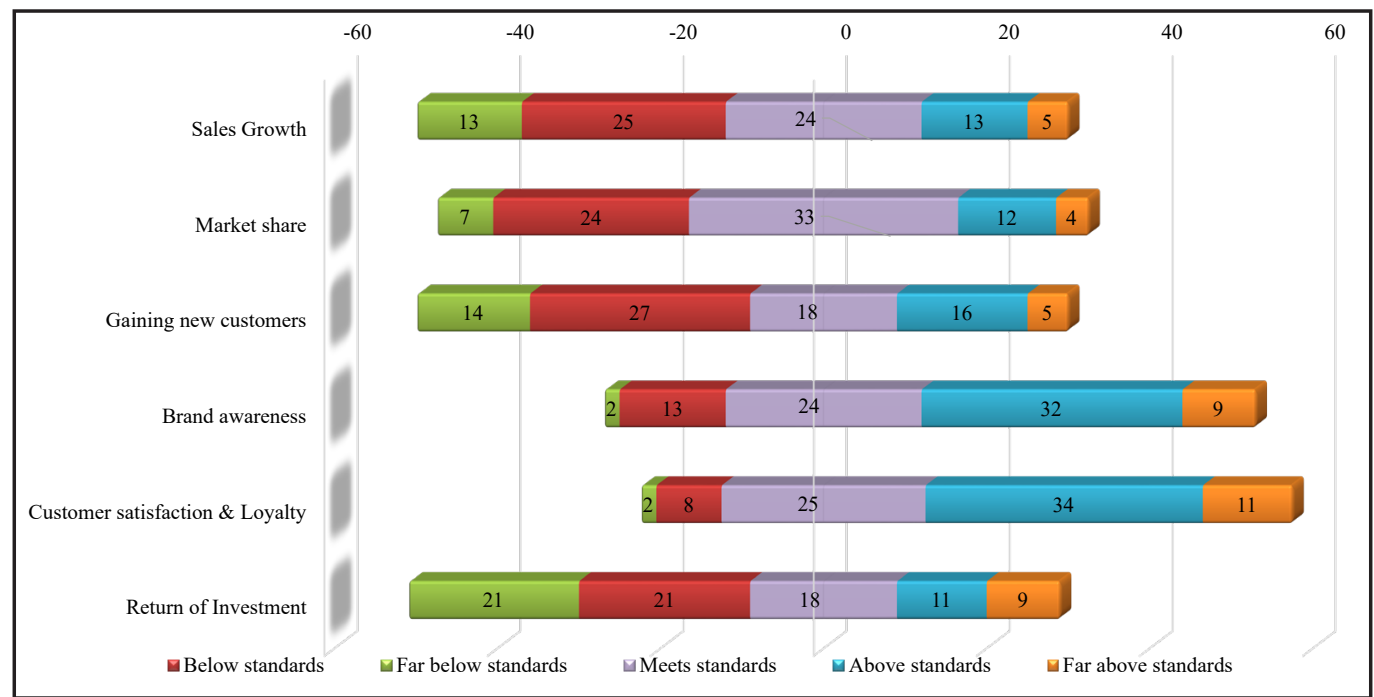

Source: own research and processing

Figure 1: Evaluation of the key performance indicators of wine producers. 
at the centre of their activities. In areas focused on finance (sales growth, return on investment) and the market (gaining new customers, market share), the percentage of companies is worse and does not meet the required standards.

Each of the above indicators requires overcoming different challenges and meeting the set goals. It is the managerial approach to marketing that defines the areas of measurement and results, and, among other things, the ability to integrate business functions, match supply and demand and transform them into purchasing processes, as well as generate financial and non-financial results. Part of our survey was also to find out the financial situation of wine producers. We asked companies to assess the financial situation for the last 3 years on a scale from 1 to 5 (where 1 reflected bad financial situation and 5 very good financial situation). As we can see from Figure 2, for half of the respondents the financial situation of wine producers is somewhere between above average and very good. Only $21 \%$ of respondents do not achieve the expected financial results.

KPIs are very important for planning, control, information support, creating transparency and support for decision-making in management (Meier, Horst, et al., 2013). In order to determine the impact of selected KPIs on the financial situation, we created a model that is linked to the first hypothesis. We used multiple linear regression to test hypothesis 1 , and the results are shown in Table 3. It shows the impact of KPIs (sales growth, market share, gaining new customers, brand awareness, customer satisfaction and loyalty, return on investment) on the financial situation of wine producers. The regression model provided a high degree of fit, which was also reflected in the correlation values $\mathrm{R}(0.769), \mathrm{R}^{2}(0.592)$, which states that the relationship between the variables is at the level of $76 \%$, which is generally considered a strong effect size. In addition, the value of $\mathrm{R}^{2}$ indicates a prediction of $59 \%$ of the financial situation from KPIs. In other words, for each unit increase in KPIs, there is a prediction of a $59 \%$ unit increase, i. e. improving the financial situation. Based on these results, the null hypothesis should be rejected, and the alternative hypothesis accepted.

Table 3 shows that brand awareness, customer satisfaction and loyalty, and return on investment have a statistical effect ( $p$-value less than 0.05) on achieving the adoption of the above KPIs to improve the financial situation. On the contrary, sales growth, market share and the acquisition of new customers did not have a statistically significant effect.

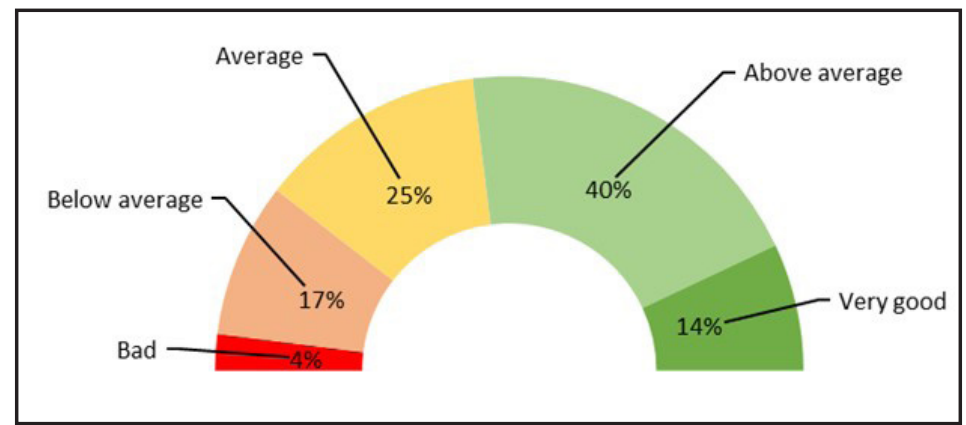

Source: own research and processing

Figure 2: Evaluation of financial situation of wine producers.

\begin{tabular}{|c|c|c|c|c|c|c|c|c|c|}
\hline Dependent Variable & $\mathrm{R}$ & R Square & F Change & df1 & $\mathrm{df} 2$ & Sig. & $\beta$ & $\mathrm{T}$ & Sig. \\
\hline \multirow[t]{7}{*}{ Financial situation } & $.769^{\mathrm{a}}$ & 0.592 & 17.659 & 6 & 73 & 0.001 & & & \\
\hline & & & \multicolumn{4}{|c|}{ Sales Growth } & -0.11 & -1.265 & 0.21 \\
\hline & & & \multicolumn{4}{|c|}{ Market share } & 0.08 & 0.872 & 0.386 \\
\hline & & & \multicolumn{4}{|c|}{ Gaining new customers } & 0.06 & 0.684 & 0.496 \\
\hline & & & \multicolumn{4}{|c|}{ Brand awareness } & 0.28 & 3.181 & 0.002 \\
\hline & & & \multicolumn{4}{|c|}{ Customer satisfaction \& Loyalty } & 0.55 & 5.963 & 0 \\
\hline & & & \multicolumn{4}{|c|}{ Return of investment } & 0.18 & 2.069 & 0.042 \\
\hline
\end{tabular}

Source: own research and processing 
Ailawadi et al. (2003) revealed the same metrics with our customer-oriented results recommendation, awareness and satisfaction that were effective in all managers' decisions. Consistent use of these metrics significantly improves results in the decision-making process. The presented study also matches with the findings of Mintz et al. (2020), who confirm the use of tools that monitor effective metrics of customers' mind-set. They were proven to be associated with achieving better performance results, which, however, depend on the employee (manager), the company, the type of industry and, of course, the way of deciding on the marketing mix. There is also a consistency between the results of the current study and the findings of Farris et al. (2015), in which the return on investment has a positive impact on the present value of future profits and meets the criterion of financial success.

As mentioned above, the questionnaire also focused on the evaluation of ICT in marketing. Figure 3 presents the results, which reflect the frequency of the use of ICT in marketing by wine producers in a visual comparison with the area of management and responsibility for the marketing department.

The results showed us that for more than half of wine producers, the use of ICT is an integral part of marketing processes. We have noticed this fact in companies where ICT is used by a marketing manager. On the other hand, $23 \%$ of companies do not use the potential of ICT in marketing. Here we found out that the marketing officer was the owner of the company, where we assume that he is in charge of a number of other responsibilities such as vineyard management, ethnological activities, wine sales and other influences such as insufficient investment solutions, lack of time or inexperience. Today, ICT and innovation play a very important role and are used to implement business action plans and strategic goals that can shift business performance. Hypothesis 2 was tested to determine whether there is a statistically significant relationship between the use of ICT supporting marketing activities and selected KPIs. Based on the results of the nonparametric Kruskall-Wallis test, we can say that there are at least 2 differences in the use of ICT with a statistically significant difference in KPIs, namely in gaining new customers ( $\mathrm{p}$-value 0.029 ) and return on investment (p-value 0.020), which support accepting the hypothesis 2 . We can also state that the other KPIs did not differ statistically and are therefore normally distributed. It is necessary to mention that for statistically significant values we analysed their averages, where we confirm the difference in the use of ICT, on the other hand, more frequent use of ICT did not have a significant positive effect on the performance of indicators.

\section{Conclusion}

To fill the gap between the empirical effectiveness of metrics and the normative system, we proposed a statistical model to evaluate the use of individual KPIs and the financial situation of wine producers. In contrast to our statement Poláková et. al. (2015) argues that, in general, there is no universal set of indicators that companies should monitor. However, if the company correctly estimates the mentioned metrics for measuring marketing activities, their implementation can be transferred to the company's financial indicators, which will lead the company to long-term sustainability

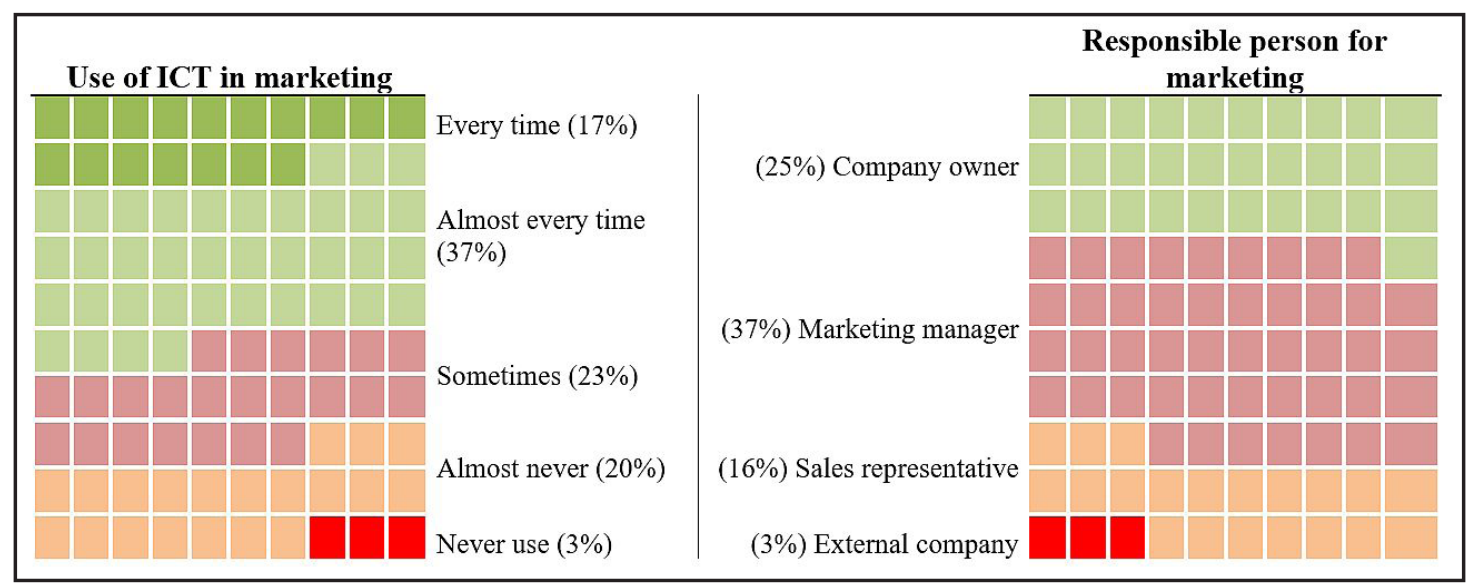

Source: own research and processing

Figure 3: Frequency of use ICT in marketing and responsible person for marketing. 
and transform it into the modern concept of Society 5.0. Our statistical model assumes that the effectiveness of indicators will differ based on companies' decisions about the current marketing mix as well as the settings of processes that responsible employees select in the belief that they are the most effective. The main contribution of the research is to provide relevant information to improve business in the field of agro-sector of wine production for the right direction of businesses. The results of the model provide us with several important insights into the use of key performance indicators in marketing. We found out that 3 KPIs - brand awareness, customer satisfaction and loyalty, return on investment - are effective for wine producers to improve their financial situation and we recommend applying them in the decision-making processes of the marketing mix. The effects of increased use are based on attracting new customers as well as achieving repeat purchases, increasing interactivity with customers and their personalization, as well as helping for more accurate business decisions. Similar research was conducted in 2020, where Mintz et. al. (2020) came to similar conclusions, adding that customer-focused metrics are more accessible to managers (1), (2) they have a significant impact on decisions and their goals, (3) they lead to improved results in the decision-making process, (4) they are easy to understand and (5) they have the potential to build long-term profitability. On the other hand, with the current marketing mix settings, the other three metrics - sales growth, market share and customer acquisition
- do not have a significant impact on improving the financial situation, so it is desirable to find more effective metrics or make changes to the marketing mix settings. These results therefore provide us with evidence supporting the orientation of wine producers mainly to the customer. Furthermore, information and communication technologies can be a major driver in business. However, the integration of ICT in marketing can vary considerably across companies. It is crucial to choose appropriate strategies to explore and seize the opportunities that ICT creates. Our research confirmed the different use of ICT in marketing for wine producers, but we cannot confirm whether the use and adaptation of ICT in business increases the performance of selected indicators. Despite the benefits and significance of this study, there are some limitations that open several doors for future research. Based on this, we would recommend replicating research on multiple samples, using multiple indicators to analyse it, applying research to multiple areas of the agro-sector and regions, and finding out the relationship between ICT, innovation, entrepreneurship, and business performance.

\section{Acknowledgements}

The results and knowledge included herein have been obtained owing to support from the following institutional grant: Internal grant agency of the Faculty of Economics and Management, Czech University of Life Sciences Prague, grant no. 2019B0009 - "Life Sciences 4.0".

Corresponding authors

doc. Ing. Klára Hennyeyová, CSc.

Department of Informatics, Faculty of Economics and Management

Slovak University of Agriculture, Tr. A. Hlinku 2, Nitra, 949 01, Slovak Republic

E-mail: klara.hennyeyova@uniag.sk

\section{References}

[1] Ailawadi, K. L., Lehmann, D. R. and Neslin, S. A. (2003) "Revenue premium as an outcome measure of brand equity", Journal of Marketing, Vol. 67, No. 4, pp. 1-17. ISSN 1547-7185. DOI 10.1509/jmkg.67.4.1.18688.

[2] An, L., Jeng, J. J., Ettl, M. and Chung, J. Y. (2004) "A system dynamics framework for sense-andrespond systems", In IEEE International Conference on E-Commerce Technology for Dynamic E-Business, pp. 6-13. ISBN 0-7695-2206-8. DOI 10.1109/cec-east.2004.11.

[3] Anderson, E. W. and Sullivan, M. W. (1993) "The Antecedents and Consequences of Customer Satisfaction for Firms", Marketing Science, Vol. 12, No. 2, pp. 125-143. ISSN 1526-548X. DOI $10.1287 / \mathrm{mksc}$.12.2.125

[4] Badawy, M., A. A. A. El-Aziz, Idress, M. A., Hefny, H. and Hossam, S. (2016) "A survey on exploring key performance indicators", Future Computing and Informatics Journal, Vol. 1, No. 1-2, pp. 47-52. ISSN 2314-7288. DOI 10.1016/j.fcij.2016.04.001. 
[5] Berg, G. (2017) "Marketing Metrics: understanding market share and related metrics", March 2017. [Online]. Available: https://www.linkedin.com/pulse/marketing-metrics-understandingmarket-share-related-glen-berg/ [accessed: 16 Feb. 2021].

[6] Diamantini, C., Genga, L., Potena, D. and Storti, E. (2014) "A semi-automatic methodology for the design of performance monitoring systems", In SEBD, pp. 111-122. ISSN 1613-0073.

[7] Elshakour, H. A. M. A., Al-Sulaihi, I. A. and Al-Gahtani, K. S. (2013) "Indicators for measuring performance of building construction companies in Kingdom of Saudi Arabia", Journal of King Saud University-Engineering Sciences, Vol. 25, No. 2, pp. 125-134. ISSN 1018-3639. DOI 10.1016/j.jksues.2012.03.002.

[8] Farris, P. W., Hanssens, D. M., Lenskold, J. D. and Reibstein, D. J. (2015) "Marketing return on investment: Seeking clarity for concept and measurement", Applied Marketing Analytics, Vol. 1, No. 3, pp. 267-282. ISSN 2054-7552.

[9] Ferrel, O. C. and Hartline D. M. (2007) "Marketing strategy", Cengage Learning, 23 p., ISBN 978-0-538-46738-4.

[10] Gotteland, D., Shock, J. and Sarin, S. (2020) "Strategic orientations, marketing proactivity, and firm market performance", Industrial Marketing Management, Vol. 91, pp. 610-620. ISSN 00198501. DOI 10.1016/j.indmarman.2020.03.012.

[11] Granberg, T. A. and Munoz, A. O. (2013) "Developing key performance indicators for airports", $3^{\text {rd }}$ ENRI international workshop on ATM/CNS, February 19, Singapore. [Online]. Available: https://www.semanticscholar.org/paper/Developing-key-performanceindicators-for-airports-Granberg-Munoz/b628479ab340dba6cc838d70a9447f4876aaf8f9 [Accessed: 20 June, 2021].

[12] Greve, H. R. (2011) "Positional rigidity: Low performance and resource acquisition in large and small firms", Strategic Management Journal, Vol. 32, No. 1, pp. 103-114. ISSN 1097-0266. DOI 10.1002/smj.875.

[13] Grønholdt, L. and Martensen, A. (2006) "Key Marketing Performance Measures", Marketing Review, Vol. 6, No. 3, pp. 243-252. ISSN 1472-1384. DOI 10.1362/146934706778605287.

[14] Hallová, M. and Hanová, M. (2019) "Information and communication technology and their influence on businesses growth in Slovakia", $3^{\text {rd }}$ International Scientific Conference - EMAN 2019, - economics and management, selected papers, Belehrad: Association of Economists and Managers of the Balkans, p. 143-148. ISSN 2683-4510. DOI 10.31410/EMAN.S.P.2019.143.

[15] Homburg, C. and Fürst, A. (2005) "How Organizational Complaint Handling Drives Customer Loyalty: An Analysis of the Mechanistic and the Organic Approach", The Journal of Marketing, Vol. 69, No. 3, pp. 95-114. ISSN 1547-7185. DOI 10.1509/jmkg.69.3.95.66367.

[16] Charter, M., Peattie K., Ottman J. and Polonsky M. J. (2006) "Marketing and sustainability", [Online]. Available: https://cfsd.org.uk/smart-know-net/links/smart-know-net.pdf [Accessed: 28 Feb. 2021].

[17] Jain, M. W. S. C., Haley T. G. and Voola, R. (2012) "Marketing: Planning and strategy", Cengage Learning, $1^{\text {st }}$ edition, ISBN 978-0170189392.

[18] Khalifa, M. and Khalid, P. (2015) "Developing strategic health care key performance indicators: a case study on a tertiary care hospital", Procedia Computer Science, Vol. 63, pp. 459-466. ISSN 1877-0509. DOI 10.1016/j.procs.2015.08.368.

[19] Keck, I. R. and Ross, R. J. (2014) "Exploring customer specific KPI selection strategies for an adaptive time critical user interface", Proceedings of the $19^{\text {th }}$ international conference On intelligent user interfaces, pp. 341-346. ISBN 978-1-4503-2184-6. DOI 10.1145/2557500.2557536.

[20] Krizanova, A, Lăzăroiu, G, Gajanova, L, Kliestikova, J, Nadanyiova, M. and Moravcikova, D. (2019) "The Effectiveness of Marketing Communication and Importance of Its Evaluation in an Online Environment", Sustainability, Vol. 11, No. 24. ISSN 2071-1050. DOI 10.3390/su11247016. 
[21] Kumar, V., Rahman, Z., Kazmi, A. A. and Goyal, P. (2012) "Evolution of Sustainability as Marketing Strategy: Beginning of New Era", Procedia - Social and Behavioral Sciences, Vol. 37, pp. 482-489. ISSN 1877-0428. DOI 10.3390/su11247016.

[22] Meier, H., Lagemann, H., Morlock, F. and Rathmann, Ch. (2013) "Key performance indicators for assessing the planning and delivery of industrial services", Procedia CIRP, Vol. 11, pp. 99-104. ISSN 2212-8271. DOI 10.1016/j.procir.2013.07.056.

[23] Mintz, O., Gilbride, T. J., Lenk, P. and Currim, I. S. (2021) "The right metrics for marketingmix decisions", International Journal of Research in Marketing, Vol. 38, No. 1, pp. 32-49. ISSN 0167-8116. DOI 10.1016/j.ijresmar.2020.08.003.

[24] Mittal, V. and Kamakura, W. A. (2001) "Satisfaction, Repurchase Intent, and Repurchase Behavior: Investigating the Moderating Effect of Customer Characteristics", Journal of Marketing Research, Vol. 38, No. 1, pp. 131-142. ISSN 1547-7193. DOI 10.1509/jmkr.38.1.131.18832.

[25] Ning, Z., Jian-hai, W. and Jia-xin, W. (2011) "Design Study on Human-Computer Interface in KpiSystem of Enterprises", International Conference on Applied Informatics and Communication, Springer, Berlin, Heidelberg, pp. 189-195. ISSN 1865-0937. DOI 10.1007/978-3-642-23223-7_24.

[26] O'Sullivan, D., Abela, A.V. and Hutchinson, M. (2009) "Marketing performance measurement and firm performance: Evidence from the European high-technology sector", European Journal of Marketing, Vol. 43, No. 5/6, pp. 843-862. ISSN 0309-0566. DOI 10.1108/03090560910947070.

[27] Peng, W., Rose, P. C. and Sun, T. (2011) "Semi-automatic system with an iterative learning method for uncovering the leading indicators in business processes", U.S. Patent No. 8,010,589, Washington, DC: U.S. Patent and Trademark Office. [Online]. Available: https://patents.google. com/patent/US8010589B2/en [Accessed: 2 Feb. 2021].

[28] Petril'ák, M., Janšto, E. and Horská E. (2020) "Communication of Local farmer's products through Facebook: The case study of Naše-Vaše", Communication Today, Vol. 11, No. 1, pp. 150-163. ISSN 1338-130X.

[29] Poláková, J., Koláčková, G. and Tichá, I. (2015) "Business model for czech agribusiness", Scientia Agriculturae Bohemica, Vol. 46, pp. 128-136. ISSN 1805-9430. DOI 10.1515/sab-2015-0027.

[30] Rust, R. T., Lemon, K. N. and Zeithaml, V. A. (2004) "Return on Marketing: Using Customer Equity to Focus Marketing Strategy", Journal of Marketing, Vol. 68, No. 1, pp. 109-127. ISSN 1547-7185. DOI 10.1509/jmkg.68.1.109.24030.

[31] Sekaran, U. and Bougie, R. (2010) "Research methods for business: A skill-building approach", $5^{\text {th }}$ ed. Haddington: John Wiley \& Sons, ISBN 978-1-119266846.

[32] Stefanovic, N. (2014) "Proactive supply chain performance management with predictive analytics", The Scientific World Journal, pp. 1-14. ISSN 1537-744X. DOI 10.1155/2014/528917.

[33] Suryadi, K. (2007) "Key performance indicators measurement model based on analytic hierarchy process and trend-comparative dimension in higher education institution", International Symposium on the Analytic Hierarchy Process (ISAHP), Vina Del Mar, Chile, 3 August. ISSN 1556-8296.

[34] Shaw, M. E. (1981) "Group dynamics: The psychology of small group behavior", McGraw-Hill College, ISBN 978-0-070565012.

[35] Šedík, P., Pocol, C. B., Horská, E. and Fiore, M. (2019) "Honey: food or medicine? A comparative study between Slovakia and Romania", British Food Journal, Vol. 121, No. 6, pp. 1281-1297. ISSN 0007-070X. DOI 10.1108/BFJ-12-2018-0813.

[36] Šimek, P., Vaněk, J. and Jarolímek, J. (2008) "Information and communication technologies and multifunctional agri-food systems in the Czech Republic", Plant, Soil and Environment, Vol. 54, No. 12, pp. 547-551. ISSN 1214-1178. DOI 10.17221/426-PSE.

[37] Varadarajan, P. R., Jayachandran, S., and White, J. C. (2001) "Strategic interdependence in organizations: deconglomeration and marketing strategy", Journal of Marketing, Vol. 65, No. 1, pp. 15-28. ISSN 1547-7185. DOI 10.1509/jmkg.65.1.15.18129. 
[38] Wangenheim, F. and Bayón, T. (2004) "Satisfaction, loyalty and word of mouth within the customer base of a utility provider: Differences between stayers, switchers and referral switchers", Journal of Consumer Behaviour, Vol. 3, No. 3, pp. 211-220. ISSN 1479-1838. DOI 10.1002/cb.135.

[39] Warlop, L., Ratneshwar, S. and Van Osselaer, S. M. (2005) "Distinctive brand cues and memory for product consumption experiences", International Journal of Research in Marketing, Vol. 22, No. 1, pp. 27-44. ISSN 0167-8116. DOI 10.1016/j.ijresmar.2004.02.001. 